The Writing of Prescriptions.

8.W.W. wites: In the last issue of the BRITISH MEdical Journal, I notice another attempt to denounce the use of the customary symbols in
prescription writing. The fact of a fatal misadventure having recently occurred has apparently prompted the writer in this instance, and he thinks that "at this time of day we can afford to dispense with these symbols considering the danger to human life ......." Would "J.M.Y." not think it advisable to dispense with the "opium " also, for the very same reason "at this time of day"? The mishap referred to was same reason "at this time of day"? The mishap referred to was person for whom it was in no wise intended, and to whom it should person for whom it was in no wise intended, and to whom it should naturally be quite unintelligible. What has a " nurse" got to do with for a qualified chemist, and if they are invariably transferred to his for a qualified chemist, and if they are invariably transferred to his English on the label attached to the medicine, and mistakes cannot occur. I see no reason for the change suggested by "J.M.Y." (and by others who have already trotted out similar suggestions), and am of opinion that, should the change be adopted, it would lead to very much greater danger in the same direction. No; life is too short to enable (which language is, I presume, implied by "terms understood by all") (whbreviations would, of course, result, increasing very materially the Abbreviations would, of course, result, increasing ver'y materially the probability of such mishaps. I think it more than probable that (alas! a much-neglected item in professional education nowadays) will (alas! a much-neglected item in professional education nowadays) will rigidly adhere to the symbols which experience has proved to be exceedingly convenient, thoroughly efficient, and absolutely safe-if
used only by those who know how-from ages past to "this time of
day."

The late Inspector-General John Murray, M.D.

WE regret to find that we were led into error in our notice of the late Dr. John Murray of the Bengal Medical Service by that usually very correct compilation, The Index Catalogue of the Library of the Surgeon. General, U.S.A. In its pages there is some confusion between two
Dr. John Murrays. Dr. John Murray, who died in July last, graduated Dr. John Murrays. Dr. John Murray, who died in July last, graduated Edinburgh in the year r83x. The title of his graduation thesis was

LARGE Fretus : A CORRECTION

IN the note from Dr. P. O'Connell (Stillorgan Castle, co. Dublin) on Large Fœtus, published in the BRITISH MEDICAL JOURNAL of November rgth, page r60o, it should have been stated that the child was a female, and not a male as printed.

\section{CAlf Lymph.}

Public Vaccinator writes: As a public vaccinator I have experienced great inconvenience due to the poor quality of the calf lymph, which have got not from one source only, but from various, and the result has been that all have given very poor results-in many cases total failure;
in others poor vesicles that will give very little protection. Without satisfactory lymph, vaccination cannot be carried out efficiently.

The Sale of Old Medical Diplomas.

A CORRESPONDENT sends us the following cut from the Exchange and Mart, October 28th

VARIOUS.-To relatives of deceased medical men. Wanted, by a collector, old medical diplomas, a good price paid, especially
for sixteenth to eighteenth century diplomas ; any acceptable, of whatever date. -2884 s.

** It is certainly curious to find that old medical diplomas are an article of merchandise. An antiquarian would hardly care for diplomas "of whatever date."

\section{German ENTerprise in Hypodermic Syringes.}

K. writes : Is it is a known fact that one or two makers of hypodermic syringes stamp the barrel with their name, a sufficient guarantee, while the mounts and needles are of German manufacture, and the whole thing is sold retail by a chemist as of English make? Some time ago I bought a hypodermic syringe in case, barrel, two mounts, and needles the barrel stamped by a very well known manufacturer. I first had occasion to use the syringe in the country, and found that the mounts in no way fitted the barrel ; in fact, the syringe was useless. On writing direct to the manufacturer of the sylinge, I get a reply that, "It is true the barrel is mine, but the Germans buy these and fix their own mounts and needles to them." Now is it not a shame that this should be so ? I suppose ninety men out of a hundred would buy a syringe with the make.

\section{ORgaNotherapy in DIABETES.}

DR. J. MCNamara ${ }^{-}$(Kensington, W.) writes : Referring to your article Organotherapy in Diabetes (BRITISH MEDICAL JOURNAL, October 22nd, r8g), I would ask permission to state that in an article on Pancreatic Diabetes in the JoURNAL of July 21st, 1894, I tried to explain, and, I believe, succeeded in explaining why pancreatic extract adminis tered by the mouth or subcutaneously failed to cure the disease. I then pointed out that the "internal secretion" of the pancreas, unlike the secretion of the thyroid, does not enter the general circulation before reaching the liver, but passes directly into the portal circulation, and glycolytic ferment directly into the portal vessels. I also suggested methols by which this could be effected.

In a further note in the JourNaL of March $27 \mathrm{th}$, 1897, I called attention to two cases reported from the Continent where pancreatic extract was administered in the method suggested with very hopeful results. I will conclude by quoting a sentence from my last note in the
JouRnAL: "If no fallacy has crept into the experiments of $M$. KaufJoURNAL: "If no fallacy has crept into the experiments of M. KaufI am unable to see why, if these suggestions are carried out, I anc ceatic "diabetes should remain an incurable discase."
LETTERS, COMMUNIOATIONS, ETC., have been received from

A Dr. J. Althaus, London: A. Ashby, M.B., Reading. B Dr. A. N. Boycott, Purley ; Mr. W. E. S. Burnett, Bowdon; Mr. B. Brooks, Hull; Mr. A. N. Brushfield, Buxton British Gynæcological Society, The Secretary of the, London; Mr. E. T. Burton, Birmingham: Mr. W. O. Beddard, Dover; F. M. Blumer, M.B., Stafford ; Messrs. Burroughs, Wellcome and Co., London; Mr, W. J. Burroughs, London; Messrs. F. and J. Bruce, London; Mr. L. A. Bidwell, London; Dr. J. B. Bird, Carlisle; Mr J. P. Bush Clifton; Dr. E. A. C. Baylor, Ash; R. Bishop, M.B., Manchester. C Cargona Com pany, Peterborough ; F. J. H. Coutts, M.B., Manchester; Mr. G. T. Coleman, Cardiff; Mr. W. Carter, Dublin; Dr. A. E. Cooper, London: Mr. J. Campbeli, Castleton; Mr. J.
Court, Staveley; C. S. R. L.; Dr. G. W. Crowe, Worcester. D Mr. H. Danvers, Court, Staveley; C. S. R. L.; Dr. G. W. Crowe, Worcester. D Mr. H. Danvers, Bordighera: Dr. W. B. Drummond, Edinburgh; Dr. E. W. Diver, Jarrow-on-Tyne. Enfield Cycle Company, London; E. G.; W. McA. Eccles, M. B., London; Epidermis ;
C. R. Edmondson, M.B., Liverpool; J. Edgar, M.B., Glasgow. F Messrs. Fassett and C. R. Edmondson, M.B., Liverpool ; J. Edgar, M.B., Glasgow. F Messrs. Fassett and
Johnson, London ; Fides ; F. P. W.; Fair Play; A. H. Frere, M.B., Stradbroke Johnson, London; Fides; F. P. W.; Fair Play; A. H. Frere, M.B., Stradbroke ;
F.R.C.S.I.; F.R.C.S.E.; Mr. H. Faulkner, Exeter. G H. W. Gell, M.B., London; W; F.R.C.S.I.; F.R.C.S.E.; Mr. H. Faulkner, Exeter. A H. W. Gell, M.B., London; W.
T. Grant, M.B., Alexandria; Mr. W. Gordon, Salisbury; Mrs. J. McC. R. Gilmer, T. Grant, M.B., Alexandria; Mr. W. Gordon, Salisbury; Mrs. J. McC. R. Gilmer,
Belfast; G. B.; Mr. A. W. German, Liverpool : Sir J. A. Grant, M.D., Ottawa; Dr. L. G. Gelfast; G. B.; Mr. A. W. German, Liverpool: Sir J. A. Grant, M.D., Ottawa ; Dr. L. G. Greenwood, Birmingham. F Dr. W. M. Hutton, Edinburgh; Mr. W. F. Haslam, Birmingham; Mr. F. Haydon, London; Dr. J. B. Huber, New York; Rev. J. W. Horsley, London; Dr. J. P. Henry, London; H. M. F. Mr. J. R. Hill Fdinburgh; Mr. F. A Humphry, Brighton; Dr. T. B. Hyslop, London; Mr. W. H. J. Huthwaite, Skipton-inCraven. I I Inoramus. J Dr. J. Johnston, Bolton; Mr. G. Joynson, Northwich. K Dr. T. N. Kelynack, Manchester; E. M. Knowling, M.B., Tenby. I Mr. J. LilwallK Dr. T. N. Kelynack, Manchester; E. M. Knowling, M.B., Tenby. I Mr. J. Lilwall-
Cormac, Burton-on-Trent ; D. Love, M.B., Cumbernauld; Dr. Levillain, Nice; R. C. Cormac, Burton-on-Trent ; D. Love, M.B., Cumbernauld; Dr. Levillain, Nice; R. C. Portsmouth; T. Laird, M.B., Heywood. M Dr. W. Milligan, Manchester; Messrs, Mayer and Meltzer, London; Mr. W. Marriott, London; Member; W. J. McCardie, T.B., Birmingham; Mr. H. H. B. McLeod, Shrewsbury ; L. F. McDowell, M.B., Hope
Town; Dr. T. Myles, Dublin; Mr. J. R. Mackinlay, London; M. D. Macleod. M.B. Beverley; Mr. J. H. Montague, London; R. J. Mills, M.B., Norwich; Mr. J. H. Morgan, London; Mr. S. W. May, Tyldesley ; Sir W. Mac Cormac, Bart., London; A. M. Morgan, M.B., Newcastle-on-Tyne; Dr. G. R.iMurray, Newcastle-on.Tyne; Mr. E. R. Morgan, Morriston; M. O. H. ; Mr. T. C. Melhado, London; McCredy Manufacturing Syndicate, The Manager of the, London. N Mr. P. Newell, Crowborough; Nottingham MedicoChirurgical Society, The Secretary of the, Nottingham; Mr. N. E. Norway, Newquay Not a Public Vaccinator; Newport Medical Society, The Secretary of the, Newport, Mon. Dr. P. O'Connell, Stillorgan. P Public Vaccinator; Mr.J. F. Potts, Sunderland; Puzzled; Mr. J. Priestley, Lee-on-the-Solent; Mr. A. H. Prichard, London; Mr. Mr. B. Pearsall, Dublin; Dr. S. P. Phillips, London; Messrs. A. and F. Pears, London Mr. J. Plummer, Sydney; Dr. J. E. Platt, Manchester. T. Messrs. J. Raphael and Co. M. Bichardson, London; Mr. L. D. Rea, London. S. C. R. M.; Mr. W. S. Sprent Slingsby ; Sir William Stokes, Dublin; Professor S. Stockman, Edinburgh ; Mr. F. C. Simpson, Great Berkhamsted; Dr. T. D. Savill, London; Dr. G. A. Stephens, Swansea G. B. Shuter, M.B., London; Dr. A. Smart, Edinburgh; Mr. A. R. Sieveking, Sheerness; S. W. W.; Mr. O. C. Smithson, Grays. T Mr. W. Thomas, Nantwich; Mr. H. G.
Turner, Manchester; Mr. W. A. U. Thomson, Maidenhead; Mr. W. T. Thomas, Liverpool; Dr. D. G. P. Thomson, Penrith; Dr. H. Tilley, London. V Dr. M. A. Veeder yons. W Dr. F. J. A. Waring, Hove; Mr. C. H. Whiteford, Plymouth; Dr. D. Walsh, London; R. P. Williams, M.B., London; Dr. F. Willcocks, London; Mr. E. S. Wood, Cambridge : Dr. J. R. Wallace, Calcutta ; Mr. E. White, London; W. Wynne, M.B. Northam; Messrs. J. Wright and Co., Bristol; Mr. G. Whitehouse, Wrexham; Mr. G. A. Wolfendale, Crook; J. L. Waters, M.B., Hull; etc.

\section{BOOKS, ETo., RECEIVED.}

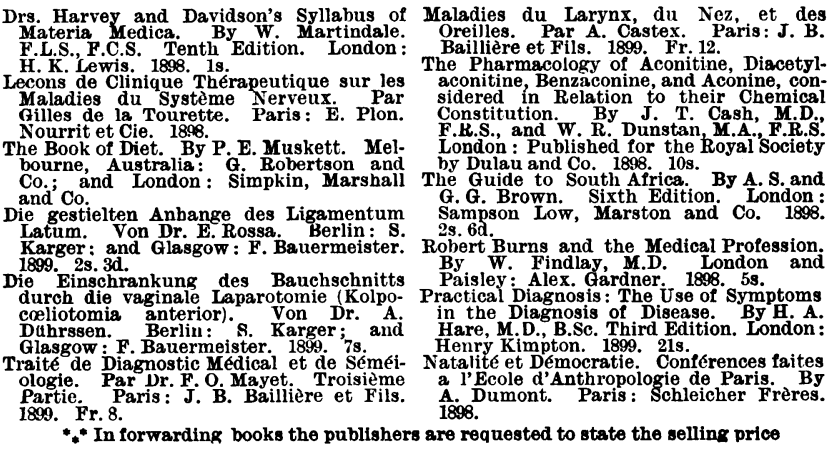

GCAME OF CHARGES FOR ADVMRTISEMGNTS IN THE

BRITISH MEDICAY JOURNAT.

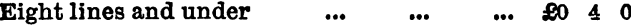

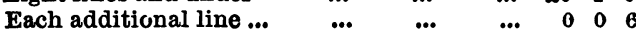

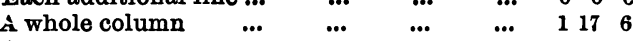

A page

An average line contains six words.

Advertisements should be delivered, addressed to the Manager, at the Office, not later than noon on the Wednesday preceding publication; and

if not paid for at the time, should be accompanied by a reference.

Post-Office Orders should be made payable to the British Medical Asso ciation at the General Post-Office, London. Small amounts may be paid in postage-stamps.

N.B.-It is against the rules of the Pcst Office to receive latters at Postes Restantes addressed either in initials or numbers. 